\title{
EXTERNAL FINANCING AND INSURANCE CYCLES
}

\author{
Anne Gron \\ Deborah Lucas
}

Working Paper No. 5229

\author{
NATIONAL BUREAU OF ECONOMIC RESEARCH \\ 1050 Massachusetts Avenue \\ Cambridge, MA 02138 \\ August 1995
}

Prepared for the NBER Conference on Property-Casualty Insurance. We thank Susan Chaplinsky, Robert Korajczyk, Mitchell Petersen and participants at the 1994 Franco-American Economics Conference for helpful comments, and Kate Evert and Dino Faleschetti for careful research assistance. Bob Spatz provided valuable technical assistance. This paper is part of NBER's research program in Corporate Finance. Any opinions expressed are those of the authors and not those of the National Bureau of Economic Research.

(C) 1995 by Anne Gron and Deborah Lucas. All rights reserved. Short sections of text, not to exceed two paragraphs, may be quoted without explicit permission provided that full credit, including $\odot$ notice, is given to the source. 


\title{
EXTERNAL FINANCING AND \\ INSURANCE CYCLES
}

\begin{abstract}
In this paper we explore the conjecture that the periodic episodes of high prices and constrained supply in the property-casualty industry are the result of temporary capital shortages. We do this by looking for increases in activities aimed at increasing capital at these times: dividend cuts, repurchase cuts, equity issues, and debt issues. We also look for evidence that the costs of raising external capital are unusually high relative to other industries by examining the market price response to security issues.

We find that there is some evidence of payout policy changes in the expected direction, and also of an increased volume of debt and equity issues following low capacity periods. However, the total amount of capital obtained by security issues or reduced payouts appears to be small relative to the observed drops in net worth, suggesting that insurers rely primarily on future retained earnings to rebuild their capital position. When property-casualty insurers do go to the capital markets, we find no evidence that they receive an unusually poor reception. In fact, the market price reaction to equity issues appears to be considerably less negative than for industrial issuers but similar to that for banks and utilities.

Anne Gron

Kellogg Graduate School of Management Northwestern University

Evanston, IL 60208

Deborah Lucas

Kellogg Graduate School of Management Northwestern University

Evanston, IL 60208

and NBER
\end{abstract}


A. Gron/D. Lucas

\section{Introduction}

The property-casualty insurance industry is characterized by an "insurance cycle"--periods of high prices and rationing followed by periods of expanding coverage and lower prices. One might expect that the high price-restricted supply phase would be short-lived due to competition between insurers for profitable new business. In fact this phase is persistent enough to observe in annual data. A number of possible explanations for this phenomenon have been suggested. In this paper we test the hypothesis that these episodes are due to temporary capital shortages which reduce the industry's ability to back risk (Winter (1989), Gron (1990)). Such shocks to industry net worth may arise either from reductions in asset value (e.g., a drop in the stock market) or from unanticipated increases in claims payments.

Past empirical studies of the cycle provide evidence that is consistent with the capital shortage hypothesis: industry capacity measures have a significant, negative relationship with price-claims margins, and large increases in price-claims margins are followed by increases in industry capacity as measured by net worth (Winter (1991b), Gron (1994a, 1994b)). Yet this evidence does not explain why capital shortages would not be quickly corrected by an infusion of new capital, particularly when profit margins are high. Unlike many industries, there appears to be no reason for a significant lag between the arrival of new capital and increased capacity. That is, the required "time to build" is short because financial capital serves primarily as a buffer against high claims costs or poor asset performance. ${ }^{1}$ This intuition is captured in models of insurance pricing without capital market frictions where price is equal to the present value of expected claims (see, for example, Fairley (1979), Hill (1979) and Myers and Cohn (1987)). In order to explain periods of unusually high profitability, any model of capital constraints for this 
industry must rely on some mechanism which delays capital inflows when industry net worth is low. ${ }^{2}$

A primary reliance on internally generated funds to finance business expansion is not special to the property-casualty industry. Most firms prefer to use internally generated funds since they avoid the costs associated with external financing. Models attempting to explain this phenomenon typically postulate that capital market imperfections such as asymmetric information increase the cost of external funds. Thus even if insurers can earn what appear to be abnormal returns on new policies, the cost of raising external funds may exceed the potential benefits from the high returns earned on new policies. The question, then, is whether plausible issue costs can explain the persistence of high price periods.

To date there has been little empirical research that systematically examines insurer financing decisions in relation to periods with and without likely capital shortages. This paper provides such an overview of insurer financing behavior and its relation to the cycle. In particular, we look for evidence that might support the notion that the cost of external capital for the property-casualty industry is sufficiently high to explain the persistence of high priceconstrained output periods. Much of our focus is on stock insurers, since these insurers should have greater access to external capital and because of data availability.

Section II begins with a description of the cyclic nature of the insurance industry over the period 1965-1990, using aggregate industry and financial statistics for a sample of stock insurers. Since reducing cash payments to stockholders is an alternative to issuing debt or equity, we look for evidence of changes in payout policy over the cycle. In Section III we describe the sample of public debt and equity issues used in the analysis of external financing, and summarize the 
evidence on how much insurers raise in the capital markets, what types of instruments are used, whether reliance on external sources has changed over time, and how financing varies with the relative abundance of capital in the industry and overall market conditions.

Evidence on the cost of external financing is examined in Section IV. A key indicator of this cost is the stock price reaction to a security issue announcement, since it reflects the revision in the market's expectations about the value of an issuing firm. To evaluate the hypothesis that external finance is unusually costly for the property-casualty industry, we measure the stock price reaction to insurer announcements of equity issues and debt issues, and compare these price changes to those for other industries. We focus primarily on equity issues since these are a relatively costly form of external finance. Asquith and Mullins (1986) find that industrial firms announcing an equity issue experience a stock price decline of $2-3 \%$ on average, which for a typical issuer represents a drop in market value equal to about $20 \%$ of the total cash raised. ${ }^{3}$ If stock price reactions to stock issues by property-casualty insurers are unusually negative, this would provide evidence that insurers face a relatively high cost of external funds. ${ }^{4}$ Section V concludes with a discussion of explanations for the insurance cycle that are alternatives to the capital shortage hypothesis.

\section{Industry Measures}

In this section we summarize the performance of stock property-casualty insurers over the period 1967 to 1990 . Using data from a variety of sources, the time path of profitability, capital structure, and payout policy is related to the insurance cycle.

\section{Measures of Profitability, Capacity, and Prices}

Insurance market conditions are usually described in terms of accounting profitability. 
Industry profitability, measured as net income divided by revenues, is graphed in figure II.1 for the $1967-1990$ period. ${ }^{5}$ A change from declining to increasing profitability marks the beginning of a high price-restricted output period. ${ }^{6}$ During these years, there are three episodes of high price-restricted output: 1969-70, 1975-76, and 1985-86. Premium price changes, net worth series, and stock indices follow a similar pattern. Gron (1994b) finds that large increases in priceclaims indices coincide with the change from decreasing to increasing accounting profitability. Large increases in the price-claims margin occur in 1969-70, 1975-76, and 1985.

Capacity is related to the volume of policies that can be supported by the industry's capital base. Although a precise regulatory measure of capacity does not exist, the time series pattern of various proxies for industry capacity are consistent with the capital shortage hypothesis (see figure II.2). For instance, here industry capacity is measured as the ratio of industry net worth to its five-year historical average. The series has relative minima at 1969, 1974, and 1984, suggesting that capacity is low immediately before price-claims margins rise. The figure also reveals that large declines in capacity immediately precede low capacity years. ${ }^{7}$

Finally, figure II.3 displays annual returns for A.M. Best's property-casualty company stock index for the years $1970-1987 .{ }^{8}$ Data for more recent years is unavailable. The stock return series show a pattern similar to the other industry aggregates: returns of property-casualty firms reach a relative minimum in 1974 and 1984, with substantial increases in annual returns in the years immediately following these relative minima.

For comparison to the above aggregates, we also collected data on a sample of large property-casualty and multiline insurers listed in quarterly and/or annual Compustat for the 197092 period. Data for 38 different insurers are available from this source, but not all insurers were 
listed for the entire period. Data for 1970-72 are particularly sparse, and for the remainder of the 1970s there are an average of 21 observations per year. Observations per year increase to about 30 in the early 1980 s, and increase to 35 by the end of the period. ${ }^{9}$

Figure II. 4 shows the annual means of income normalized by sales or assets for this Compustat sample. The pattern found in the aggregate industry ratios is also seen here. Clearly 1985 was a year of particularly low income. Income was relatively low as well in 1970 and 1974. The mean annual ratio of liabilities to assets is generally increasing over the period. While the ratio declines somewhat in the latter part of the 1970 s, there is really only one distinct feature which is the significant increase in liabilities relative to assets in 1985 .

\section{Payout Policy}

Internally generated funds represent by far the largest source of capital for U.S. corporations. ${ }^{10}$ The primary advantage of internal financing is that it avoids the direct and indirect costs associated with issuing new securities. Clearly one way for firms to increase available internal funds is to cut back on payouts to shareholders, i.e., by reducing dividends or repurchases. While stock repurchases are considered discretionary, managers appear reluctant to reduce dividends except when under strong financial pressure to do so, in part due to the negative stock price reaction to dividend cuts. As a result, we expect to see an overall reduction in dividend growth rates and repurchase activity during periods of industry-wide capital shortages, with a potentially larger response of repurchases than of dividends.

One measure of dividend policy is the payout ratio, which measures the dollar dividend per share divided by earnings per share. Figure II. 5 plots the payout ratio for the period 1972 to 1990 using data from quarterly Compustat on property-casualty insurers, as described above. 
Notice that the payout ratio hovers between $25 \%$ and $60 \%$ for most of this period, with a noticeable increase in the payout ratio in the two years preceding the earnings crash of 1984-85. As in other industries, it appears that insurers follow a fairly smooth payout policy. The exception to this was the period $1984-85$, at which time dividends clearly fell by much less than earnings. If $1975-76$ and $1985-86$ are taken to be periods of capital shortages, the graph is consistent with the idea that payout ratios were somewhat reduced in the years immediately following these episodes, perhaps in an effort to rebuild capital. Similar conclusions can be drawn from the time series behavior of the dividend yield (dividend divided by price).

To look more closely at these changes, Figure II.6 shows the proportional changes in aggregate stockholder dividends over the $1967-92$ period. ${ }^{11}$ Consistent with the idea that dividends are only reduced under duress, negative growth is rarely observed. In fact years with dividend cuts coincide with turning points in the cycle: 1970, 1974-75, and 1984, suggesting some attempt was made to conserve scarce capital.

As discussed above, an alternative to dividends is to use share repurchases to distribute cash. Although still less important than dividends, the volume of repurchases by U.S. firms has grown steadily over the past several decades. Figure II.7 plots equity repurchases and issues over the $1975-1990$ period, also using data from quarterly Compustat for firms classified as propertycasualty insurers. The data again support the idea that insurers were trying to rebuild capital following the 1984-85 shock. In particular, no repurchases for the 32 firms in the sample were reported from 1985-87, but repurchase activity resumed in 1988 and thereafter. Interpreting repurchase activity for the earlier period is more problematic because repurchases are less prevalent, and because data is only available for 12 firms. The increase in repurchase activity in 
1983-84 is consistent with the rise in dividend payout ratios in the same years, but it is somewhat surprising in light of the drop in net worth that appears at about the same time.

\section{Firm Financing Behavior}

The statistics presented in the previous section suggest that profitability in the propertycasualty industry has varied markedly over time, with episodes of high prices and restricted output in $1969-70,1975-76$ and most notably in 1985-86. Although payouts to shareholders grew at a slower rate in the high price-restricted output phases, the large fluctuations in capital do not appear to be substantially offset by efforts to conserve internally generated funds via changes in payout policy.

An alternative to financing with retained earnings is to raise capital externally. Here we focus on public debt and equity issues as sources of external funds, and examine how the volume of new issues in the property-casualty industry has varied over time and with market conditions. We concentrate on debt and equity because of data availability and because these sources are likely to account for a large fraction of external financing. It should be noted, however, that other sources of external finance including bank loans, private placements of debt and equity, and other types of securities such as convertible bonds or warrants are also potential sources of capital.

\section{Data}

We obtained all SEC-registered debt and equity announcement and issue dates for the property-casualty industry from the Securities Data Company (SDC). Since 1970, this sample includes 171 equity issues by 100 different property-casualty companies, reinsurers and holding companies, totalling over $\$ 11.5$ billion. We also obtained information on companies in these 
categories for 142 debt issues that yielded over $\$ 13.6$ billion. The data obtained includes the total value of the issue, the number of shares issued in the case of equity, and the type of debt or equity issued (e.g., preferred, common, subordinated). For companies with a listed issue date but no announcement date, the announcement date was obtained when possible from the Wall Street Journal Index. The sample does not include companies that announce an issue but then do not follow through with it.

\section{The Volume of Equity Issues Over Time}

The time series pattern of external financing in the property-casualty industry can be related to potentially explanatory variables such as changes in firm and industry net worth, stock market returns, and economy-wide financing behavior. Table 1 shows the number of firms issuing equity each year and the total dollar value of issues, while Figure III.1 shows the annual dollar volume of equity issues as a fraction of industry net worth. For all series the data displays two peaks: a larger peak at 1985-1986 and a smaller peak at 1971-1972. These correspond to two of the three periods of high prices and restricted output. In the third period in which the industry data suggests a capital shortage, 1975-76, there is not such a clear peak. While total equity offered relative to industry net worth increases slightly in 1976 , the number of firms issuing equity is not significantly different from other years. As with the earlier series, the activity during the 1980 s is significantly greater than that of the preceding period.

The question arises of whether insurers issue more during certain periods because of conditions particular to the property-casualty industry, or whether they were simply following broad-based financing trends in the market. For industrial firms, the volume of equity issues varies substantially over time, with the bulk of issues clustered in so-called "hot" market periods. 
One prominent characteristic of hot market periods is that aggregate stock market returns are above average.

To examine whether property-casualty issues are clustered with those of industrial issuers, we use the classification of historical hot and cold market periods identified by Bayless and Chaplinsky (1994). For their sample of industrial firms they find that $60 \%$ of the issues occur in hot periods ( $28 \%$ of the months considered) while only $13 \%$ of the issues occur in cold periods (29\% of these months). Why this pronounced clustering of equity issues occurs remains somewhat mysterious; some have attributed it to temporal variations in adverse selection (Choe, Masulis and Nanda, 1992) while others point to fads in financing mechanisms and waves of market optimism. Whatever the explanation, the average stock price drop for industrial firms is lower during hot periods by about $2 \%$, a substantial cost differential that appears to benefit hot market issuers (Bayless and Chaplinsky, 1994). For the 137 issues in our sample that occurred over this time period, 66 occurred in hot periods while only 10 occurred in cold periods. ${ }^{12}$ This suggests issue behavior temporally similar to other equity issuers, and may explain the relatively low volume of issues in 1975-1976 despite the apparent capital shortage in the property-casualty industry.

\section{The Volume of Debt Issues Over Time}

The time series properties of our sample of debt issues is summarized in figures III.2, III.3, and III.4. As with equity issues, the most activity occurs in 1986, and there is more activity generally towards the end of the period. In contrast to equity issues, however, the peaks of financing activity are less pronounced. Issue volume patterns also vary across debt maturities. Short term debt issues are rare in the 1970s but are used quite frequently in the last five or six 
years of the period. Even in the later period, however, short-term debt accounts for a small fraction of total proceeds. ${ }^{13}$ The issue pattern of medium term debt over time is similar to that for equity, with proceeds as a fraction of industry net worth peaking in 1971, 1976 and 1986. Notice that the issue volume in 1976 is large relative to equity, perhaps because firms were substituting debt issues for equity issues in this cold market period. Long term debt issues, like short term issues, do not exhibit any particular correlation with industry-wide changes in net worth or market conditions.

Data on long-term debt is also available from quarterly Compustat for many of the firms in the smaller sample examined in Section II. For comparison, Figure III. 5 shows the average percentage changes in long-term debt over the 1974-89 period for the Compustat firms (which number 12 in 1974 and increase to 28 firms in 1989). As for the larger SDC sample, on average changes to debt were positive, but show no particular pattern in relation to the insurance cycle. Notice that the large percentage increases in the earlier part of the period reflect the low base of debt at that time. Figure III.6 shows the ratio of long-term debt to total assets over the same period, where total assets is measured as the sum of market equity and book liabilities. In this graph the increase in the ratio of debt to value in $1984-85$ primarily reflects the drop in stock price rather than an increase in debt.

As in the case of equity issues, it is difficult to disentangle increases in external financing due to events particular to the property-casualty industry from increases due to broader market trends. The growth of debt financing in the middle to late 1980s is consistent with large economywide increases in leverage, due in part to the more favorable tax treatment of debt following the 1986 Tax Reform Act. 


\section{Evaluating the Importance of External Finance}

As we have seen, the observed pattern of debt and equity issues is consistent with the idea that insurers use external finance to offset reductions in capital, but it could also be attributed to broader market trends. To evaluate the quantitative importance of external finance in offsetting the cycle, we compare the total amount of externally generated financing to changes in total net worth. The annual growth in real net worth for the industry is shown in figure III.7. Negative growth years are $1969,1973,1974,1981,1984,1990,1992$, where the last two are quite close

to zero. High growth years generally follow those with negative growth, and include: 1971, $1972,1975,1976,1985$, and 1986 . The use of external financing is actually greater in these high growth years, which might be explained by the lead time needed to arrange an issue. The delay could also arise if insurers wait for the market to recognize the potential for profitable expansion before issuing. Interestingly, the amount of total capital raised in equity and debt markets is not large relative to the total increase in net worth in these years. The ratio of total debt and equity funds generated to the increase in stock insurers' net worth is $13 \%$ in $1970,4 \%$ in 1976 , and $33.6 \%$ in 1985 . Of course, the amounts raised represent a much larger fraction of the net worth of the issuing firms.

To evaluate whether the relationship between issues and capacity is statistically significant, we performed the regression analysis presented in table 2 . For both equity and debt issues, we examined three measures: the number of issues, the real value of funds issued and the value of funds issued relative to industry net worth at the beginning of the year. Our explanatory variables are capacity at the beginning of the year, measured as industry net worth as of the beginning of the year divided by the 5 year historical average, and the ratio of industry liabilities to assets, as 
of the beginning of the year. ${ }^{14}$ The results in table 2 show there is a negative relationship between the industry capacity and the various measures of equity financing. This relationship is generally significant at or above the $15 \%$ confidence level. In addition, there is a positive relationship between measures of equity financing and the ratio of liabilities to assets at the beginning of the period, although this relationship is less precisely measured. On the other hand, there is no statistically significant relationship between capacity and measures of debt financing. Debt financing, like equity financing, is positively related to industry leverage as measured by liabilities relative to assets.

An often cited "capacity" statistic in the industry is the ratio of premium revenue to net worth. This ratio reflects the industry's leverage in terms of premium revenue. Under the assumption that premium revenue primarily reflects the expectation of uncertain claims costs, this ratio reflects expected costs relative to the funds available if realized costs exceed their expectations. If there is some maximum ratio of premium revenue to net worth and if insurers are at or near that limit after declines in net worth, then the percentage increase in net worth following a security issue translates into the same percentage increase in premium revenue supported. As seen from above, the increase in premium revenue that can be supported by the externally generated funds is relatively small for all years but 1985-1987.

\section{The Announcement Effect of Equity and Debt Issues}

As discussed earlier, there are significant direct and indirect costs to security issues that can discourage firms from financing otherwise attractive investment opportunities. Direct costs include underwriters fees, SEC filing requirements, distribution costs, bank charges, and so on. The largest indirect cost, usually associated with the issue of risky securities such as equity, is the 
negative market price reaction to the announcement of an issue. The argument that high pricerestricted output periods in the property-casualty industry are due to capital shortages implicitly rests on the idea that raising capital is prohibitively expensive due to these direct and indirect costs. To see if there is evidence of unusually high financing costs, in this section we measure the stock price reaction to insurance company issues of debt and equity, and compare the reaction to that for other financial and industrial firms.

\section{Equity Issues}

We focus primarily on equity issues because they provide capital in a form that is clearly acceptable to regulators, and because they are a relatively expensive form of financing. Not only are there significant direct costs involved in equity issues estimated to range from $1 \%$ to $5 \%$ of the value issued, but issuers typically experience a significant drop in their stock price as well.

One commonly accepted explanation for the announcement day price drop is that asymmetric information between managers and potential shareholders creates an adverse selection problem (Myers and Majluf (1984)). Firms that realize their stock is overvalued have an incentive to issue additional stock since their current shareholders will benefit at the expense of the new buyers. Similarly, managers who believe their stock is undervalued will avoid issuing equity. Potential buyers, realizing these incentives, react to the announcement of an equity issue as a signal that the stock is overvalued, and hence the market price falls. Consequently, many firms whose stock is not undervalued would forego or postpone valuable investment opportunities or rely more on internal financing rather than issue equity at a depressed price. ${ }^{15}$

Empirical studies of stock price behavior around equity issues [e.g., Masulis and Korwar (1986), Mikkelson and Partch (1986), Korajczyk, Lucas and McDonald (1990)] reveal a number 
of regularities that are consistent with this basic adverse selection story. For industrial firms, stock prices fall an average of $2-3 \%$ at the announcement of an issue. Following this, there is a further drop of about $.5 \%$ for firms that follow through with an issue. Studies have also found that issuing firms have abnormally high returns in the months preceding the announcement of an issue, an observation that also can be explained by the impact of adverse selection in a multiperiod setting (Lucas and McDonald (1990)). More recent evidence suggests that issuing firms experience negative abnormal returns in the three to five years after they issue, suggesting that the price drop at announcement underestimates the bad news associated with the average issue (Ritter et. al., 1994).

The price behavior for financial firms and utilities is somewhat different. For instance, the announcement date stock price drop for public utilities is considerably lower than for industrial firms. The differential may be due to the fact that utilities issue more frequently so that the announcement more likely to be anticipated, and also that they have more easily observable investment projects. The fact that their rate of return is regulated may also have an impact. In a study of the banking industry, Cornett and Tehranian (1994) conjecture that the stock price reaction to equity issues by commercial banks will be more pronounced for "voluntary" rather than "involuntary" issues, and find some evidence supporting this claim. An involuntary issue is defined as occurring when the issuing bank is in violation of regulatory capital adequacy requirements. ${ }^{16}$

On a priori grounds it is not clear how the indirect costs of equity issues should be expected to change over the insurance cycle. In analogy to the case of commercial banks studied by Cornett and Tehranian (1994), one might expect the stock price reaction to equity issues to be 
less negative during the high price-constrained supply phase because investors can observe the need for capital and the potential for profitable investment. This suggests that insurers would face relatively low costs of issuing equity in these periods, making it more puzzling that supply shortages persist. On the other hand, insurance is an information-intensive business, and it is plausible that managers have a much better idea of the value of their assets and liabilities than does the market. Even during a high price-constrained output phase, an equity issue could reveal that a firm was hit with a particularly large number of costly claims or low asset returns, forcing it to go to the equity market.

\section{i. Results}

To assess the market price reaction to an insurer equity issue, we calculate abnormal returns over the 20 day window surrounding the announcement of an equity issue. The abnormal return is calculated as the daily return of the issuing company minus the daily return of a value weighted market index. ${ }^{17}$ These returns are taken from the Center for Research on Security Prices (CRSP) data tapes, which provide information on NYSE/AMEX and NASDAQ stocks. Of the 171 equity issue events obtained from SDC and after excluding brokerages, we were able to match 113 to CRSP data using CUSIP identification numbers. Cumulative abnormal returns were calculated by compounding the average daily abnormal returns over the 20 day window.

On day 0 (the announcement date) the average price drop across the 113 events for which data were available was $1.1 \%$, with a standard deviation of $2.69 \%$. Although the drop is not statistically significant, it is much larger than the typical daily abnormal return in other days in the event window, which never exceeds $.45 \%$. In contrast to previous studies on industrial firms, no apparent price drop is observed on day -1 , suggesting little information leakage prior to the 
announcement. The standard deviation of abnormal returns is fairly constant over the event window. Figure IV.1 summarizes the behavior of abnormal returns for issuing firms. As a robustness check, we also calculated the price reaction excluding firms that were classified as primarily brokerages or health and accident, and including all firms for which data was available. The price drop and variance for the different samples were almost identical.

Because of the small sample size, it is hard to draw strong conclusions about how this price reaction compares to that of other industries. It appears, however, that the price drop is relatively small compared to the experience of industrial firms which typically drop $2-3 \%$ in value. It is more similar to the price drop in response to bank equity issues of $1.56 \%$ for voluntary issues and $.64 \%$ for involuntary issues found by Cornett and Tehranian (1994). This relatively small price drop exacerbates the puzzle of why insurers do not rely more on external financing during the high price-constrained supply phase of the insurance cycle.

\section{ii. The Effect of Market Climate}

Recall that many property-casualty industry issues occur during economy-wide "hot market" periods, and that for industrial firms the price drop is lower at these times. To see whether insurers issuing in hot markets also gain a price advantage, we divide the sample between "hot" and "not hot" issuers, again using the date classifications suggested by Bayless and Chaplinsky $(1994):{ }^{18}$ 
Hot

$$
\begin{array}{ll}
11 / 80-03 / 84 & 03 / 69-10 / 80 \\
07 / 85-09 / 87 & 04 / 84-06 / 85 \\
04 / 88-10 / 88 & 10 / 87-03 / 88 \\
& 11 / 88-10 / 89
\end{array}
$$

In our sample 52 announcements occur in identified "hot" periods and 26 announcements occur in "not hot" periods. Consistent with the findings for industrial firms, the average price drop for the "hot" market issuers was only .7\%, while for "not hot" market issuers the drop was $1.6 \%$. For the unclassified post-October 89 period, the average price drop for the 36 events in our sample is $1 \%$. In none of the subperiods is the price drop statistically significantly different from zero, although (with the exception of the hot market group) they are at least twice as large as the average price change on any other day in the 20 day window. ${ }^{19}$

iii. Cross-sectional Influences

The price drop at issue announcement is potentially affected by cross-sectional factors such as the size of the issue. In a regression of the price drop on issue size, however, no significant relationship was detected.

\section{Debt Issues}

In comparison to most other companies insurers have little ordinary debt in their capital structure. One explanation for this is that their policyholders already have debt-like claims on the firm's cashflows, making additional fixed obligations less attractive. Still, issuing debt that is 
junior to the claims of policyholders is viable way to increase capital, particularly as a short-term measure. For most firms issuing debt is a less costly alternative to issuing equity, both because of lower direct costs and indirect costs. Indirect costs are lower because it is fairly easy for management and the market to agree upon the value of a low risk security such as debt. This implies that one would not expect to see a large price drop upon the announcement of a debt issue, a conjecture that has been confirmed by earlier empirical work on industrial firm issues.

To see how the market responds to property-casualty industry debt issues we follow the methodology of the previous section, computing average abnormal returns in the 20 day window centered on debt issue announcement dates (see figure IV.2). For the 82 debt issues for which announcement dates could be matched to stock return data, the price drop on the announcement date averaged $.5 \%$. As expected, the drop was statistically insignificant and similar in magnitude to abnormal returns on other days in the window. It appears that the market receives propertycasualty debt issues similarly to those of other firms.

\section{Concluding Remarks}

In this paper we have explored the conjecture that the periodic episodes of high prices and constrained supply in the property-casualty industry are the result of temporary capital shortages. To do this we look for increases in activities aimed at increasing capital at these times: dividend cuts, repurchase cuts, equity issues, and debt issues. We also look for evidence that the costs of raising external capital are unusually high relative to other industries by examining the market price response to security issues.

There is some evidence of payout policy changes in the expected direction, and also of an increased volume of debt and equity issues following low capacity periods. The total amount of 
capital obtained by security issues or reduced payouts, however, appears to be small relative to the observed drops in net worth, suggesting that insurers rely primarily on future retained earnings to rebuild their capital position. When property-casualty insurers do go to the capital markets we find no evidence that they receive an unusually poor reception. In fact the market price reaction to equity issues appears to be considerably less negative than for industrial issuers, but similar to that for banks and utilities.

These findings make the seeming reluctance of property-casualty insurers to rely more heavily on external capital markets somewhat surprising, and suggest several possibilities to be explored in future research. One interpretation of our evidence is that the cycle should not be attributed to periodic shortages of capital, but instead to other factor(s) that remain to be identified. For instance, one explanation of the cycle that does not rely on capital market imperfections is that premiums rise in response to new information about expected cost increases. Changes in loss distributions produce large reductions in industry net worth, and insurers update their estimates of expected claims and increase prices accordingly. Since current cost data do not fully reflect this new information, the relation between industry capacity and operating margins temporarily shifts. Under this alternative hypothesis, we would not expect insurers' cost of external financing to be unusually high, nor would insurance prices necessarily increase with low capital.

On the other hand, although the incorporation of new public information into prices may be a factor in the cycle, new information alone is unlikely to explain a number of phenomena that appear to be related to the cost of capital or other asymmetric information problems. For one, periods of high prices also appear to be periods of rationing. The fact that insurers temporally 
concentrate their equity issues during periods in which other firms are issuing equity and in periods following an increase in industry profitability also suggests that asymmetric information is a factor.

A second possibility is that the costs of raising external capital are much higher than the observed price reactions to equity issues suggest, particularly for the firms that choose not to issue securities. A shortcoming of our method is that we can only observe costs for the firms that find it profitable to go ahead with an issue, and even in this case we rely on an indirect measure of the costs (i.e., the market price response). Several aspects of the data do point towards high costs: the propensity of firms to issue in hot markets, the somewhat higher cost of issuing in cold markets, and the small volume of equity and debt issues overall.

Finally, an interesting trend in the data is the significant increase in the use of debt and equity issues by insurers over time. If capital availability did play a major role in past fluctuations, we would expect to see less pronounced cycles in the future as the size and informational efficiency of capital markets continues to increase. 
A. Gron/D. Lucas

\section{References}

A.M. Best Company Best's Aggregates and Averages, Property/Casualty edition, various years.

A.M. Best Company, 1988. "1987 Insurance Stock Trends," Best's Review, Property/Casualty edition, March.

Asquith, Paul, and Mullins, David W., Jr. 1986. "Equity Issues and Offering Dilution." Journal of Financial Economics 15 (January/February): 61-89.

Bayless, Mark, and Chaplinsky, S., 1994. "Favorable Pricing and Hot and Cold Equity Issue Markets," working paper, Northwestern University

Brown, S. J., and Warner, J. B. 1985. "Using Daily Stock Returns: The Case of Event Studies." Journal of Financial Economics 14 0: 3-31.

Cagle, Julie A.B. and Scott E. Harrington, 1994. "Insurance Supply with Capacity Constraints and Endogenous Insolvency Risk," Working paper.

Chevalier, J. and Scharfstein, D., 1994. "Capital Market Imperfections and Countercyclical Markups: Theory and Evidence." NBER working paper. 
Choe, Masulis, R., and Nanda, V.

Collins, D. W., and Dent, W. T. 1984. "A Comparison of Alternative Testing Methodologies Used in Capital Market Research." Joumal of Accounting Research 22 (Spring): 48-84.

Cornett, M.M., and Tahranian, H., 1994. "An Examination of Voluntary Versus Involuntary Security Issuances by Commercial Banks. " Journal of Financial Economics 35 (1994), 99122.

Cummins, J. David and Patricia Danzon, 1991. "Price Shocks and Capital Flows in Liability Insurance," in Cummins, J.D. and Harrington, S.E. and R.W. Klein (eds), Cycles and Crises in Property/Casualty Insurance: Causes and Implications for Public Policy Kansas City, MO: National Association of Insurance Commissioners.

Cummins, J. David and J. François Outreville, 1986. "An International Analysis of Underwriting Cycles in Property-Liability Insurance," Joumal of Risk and Insurance, pp. 246-262.

Fairley, William B., 1979. " Investment Income and Profit Margins in Property-Liability Insurance," Bell Joumal of Economics 10, Spring: pp. 192-210.

Fazzari, F.M., Hubbard, R.G., and Petersen, B.C. 1988. "Financing Constraints and Corporate Investment." Brookings Papers on Economic Activity no. 1, 141-195. 
Gron, Anne, 1990. Property-Casualty Insurance Cycles. Capacity Constraints. and Empirical Results. PhD. dissertation, Massachusetts Institute of Technology, September.

Gron, Anne, 1994a. "Capacity Constraints and Cycles in Property-Casualty Insurance Markets," Rand Journal of Economics, Spring.

Gron, Anne, 1994b. "Evidence of Capacity Constraints in Property-Casualty Insurance" forthcoming in The Journal of Law and Economics.

Hill, R. D. 1979. "Profit Regulation in Property Liability Insurance," Bell Journal of Economics, 10, Spring: pp. 172-191.

Korajczyk, R., Lucas, D., and McDonald, R., 1990. "Understanding Stock Price Behavior Around the Time of Equity Issues," in Asymmetric Information. Corporate Finance. and Investment edited by R. Glenn Hubbard, NBER

Lucas, Deborah, and McDonald, Robert L., 1990. "Equity Issues and Stock Price Dynamics," Journal of Finance, September.

Masulis, Ronald W., and Korwar, Ashok N., 1986. "Seasoned Equity Offerings: An Empirical Investigation." Journal of Financial Economics 15 (January/February): 91-118.

Mikkelson, Wayne H., and Partch, M. Megan. 1986. "Valuation Effects of Security Offerings 
and the Issuance Process." Journal of Financial Economics 15 (January/February): 31-60.

Myers, S. C., and R. A. Cohn, 1987. "A Discounted Cash Flow Approach to Property-Liability Rate Regulation," in Cummins, J.D. and S.E. Harrington (eds), Fair Rate of Return in Broperty-Liability Insurance. Boston.

Myers, Stewart C., and Majluf, Nicholas S. 1984. "Corporate Financing and Investment Decisions When Firms Have Information That Investors Do Not Have." Journal of Financial Economics 13: 187-221.

Stewart, Barbara D., 1984. "Profit Cycles in Property-Liability Insurance," John D. Long and Everett D. Randall, eds. Issues in Insurance, vol 2, American Institute for Property and Liability Underwriters, Inc., USA.

Strain, Robert, W., 1986. ed., Property-Liability Accounting.

van Aartrijk, Peter, 1985. "1984 Insurance Stock Trends," Best's Review, Property-Casualty edition, February.

Winter, Ralph A., 1988. "The Liability Crisis and the Dynamics of Competitive Insurance Markets," Yale Journal on Regulation, vol 5, pp. 455-500. 
-----, 1991a. "The Liability Insurance Market," The Journal of Economic Perspectives vol.5, Summer.

1991b. "The Dynamics of Competitive Insurance Markets," mimeo, University of Toronto. 
Figure II.I

\section{Industry Operating Income}

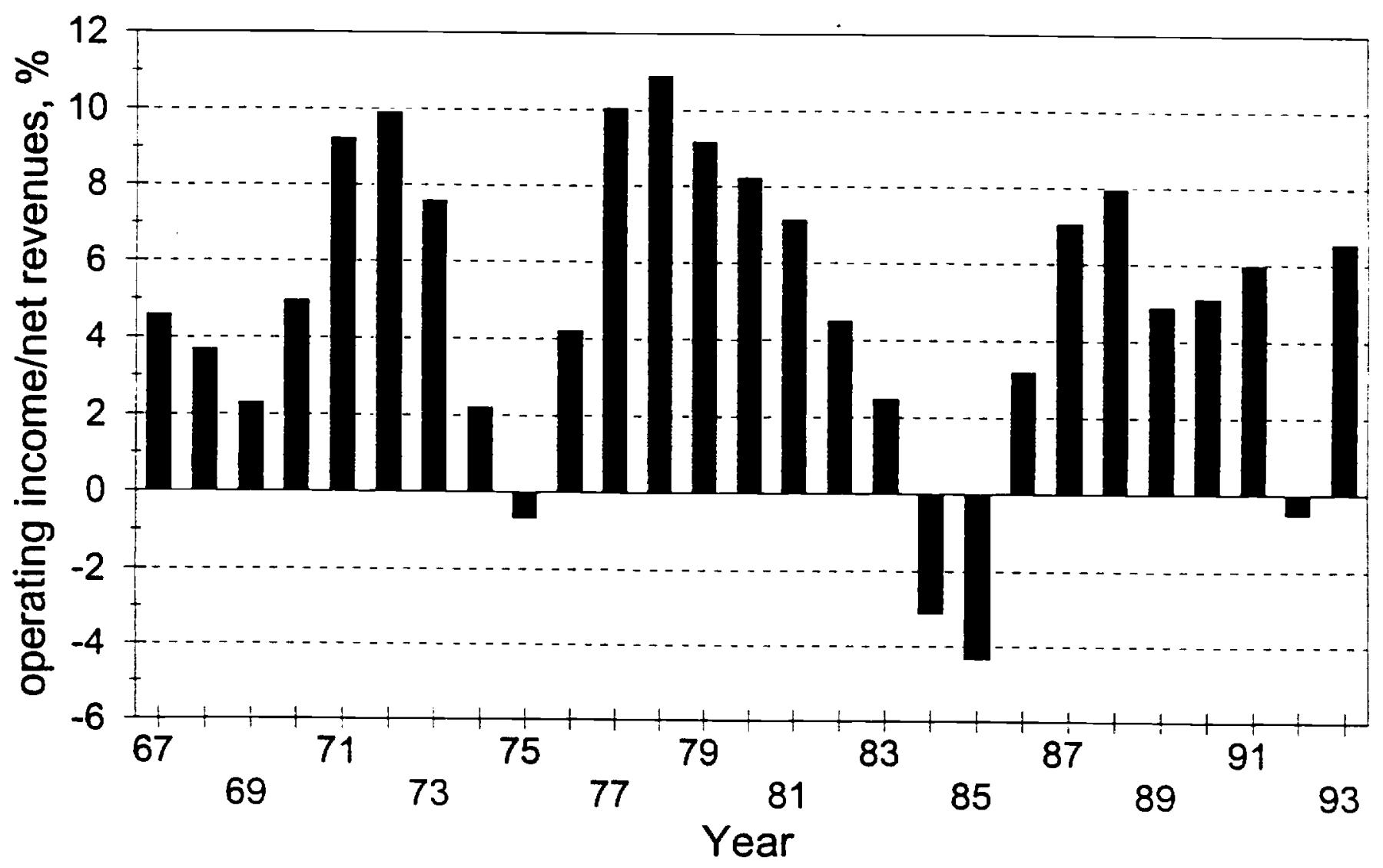


Figure II.2

\section{Industry Capacity}

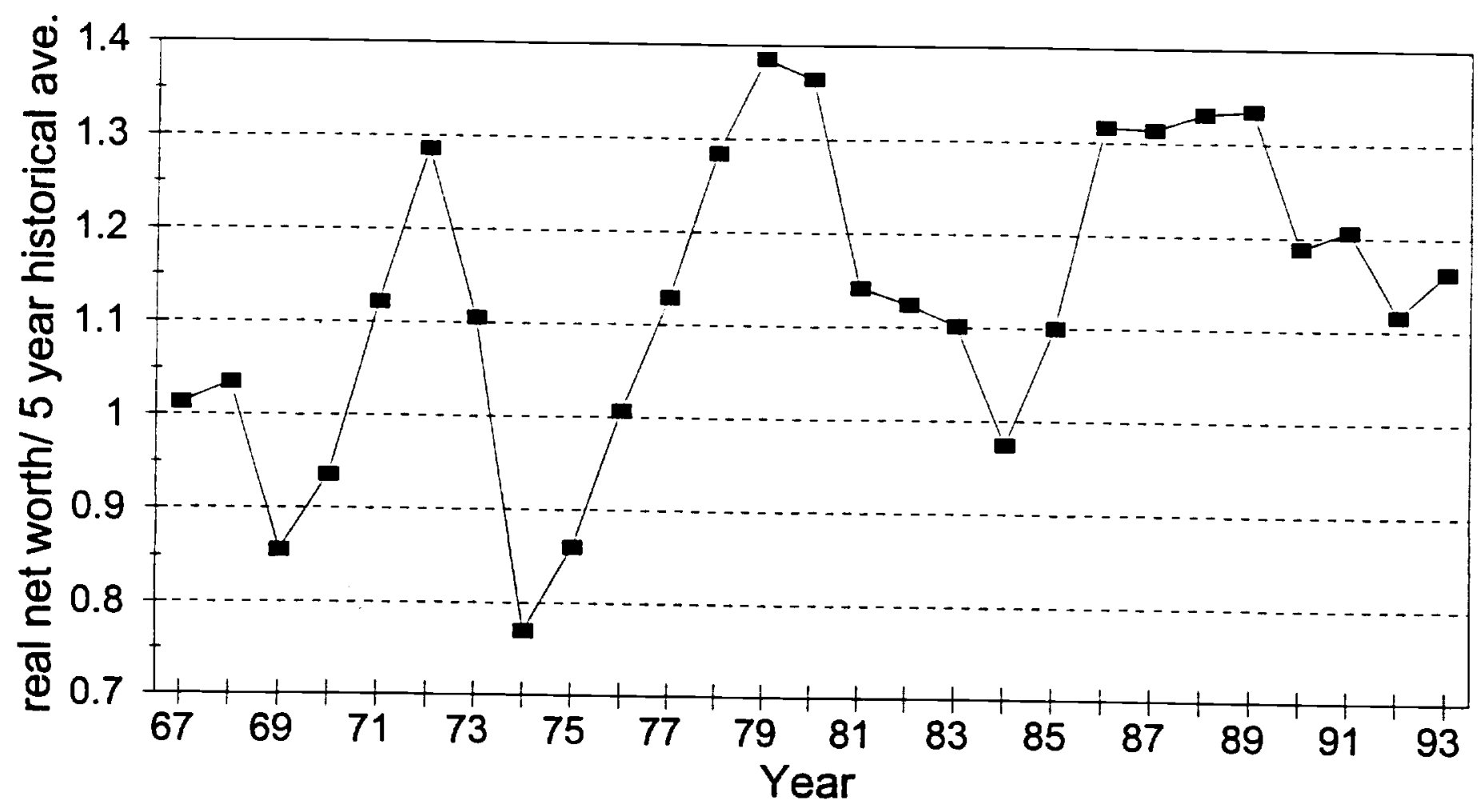


Figure II. 3

\section{Property-Casualty Stock Returns} 1970-1987

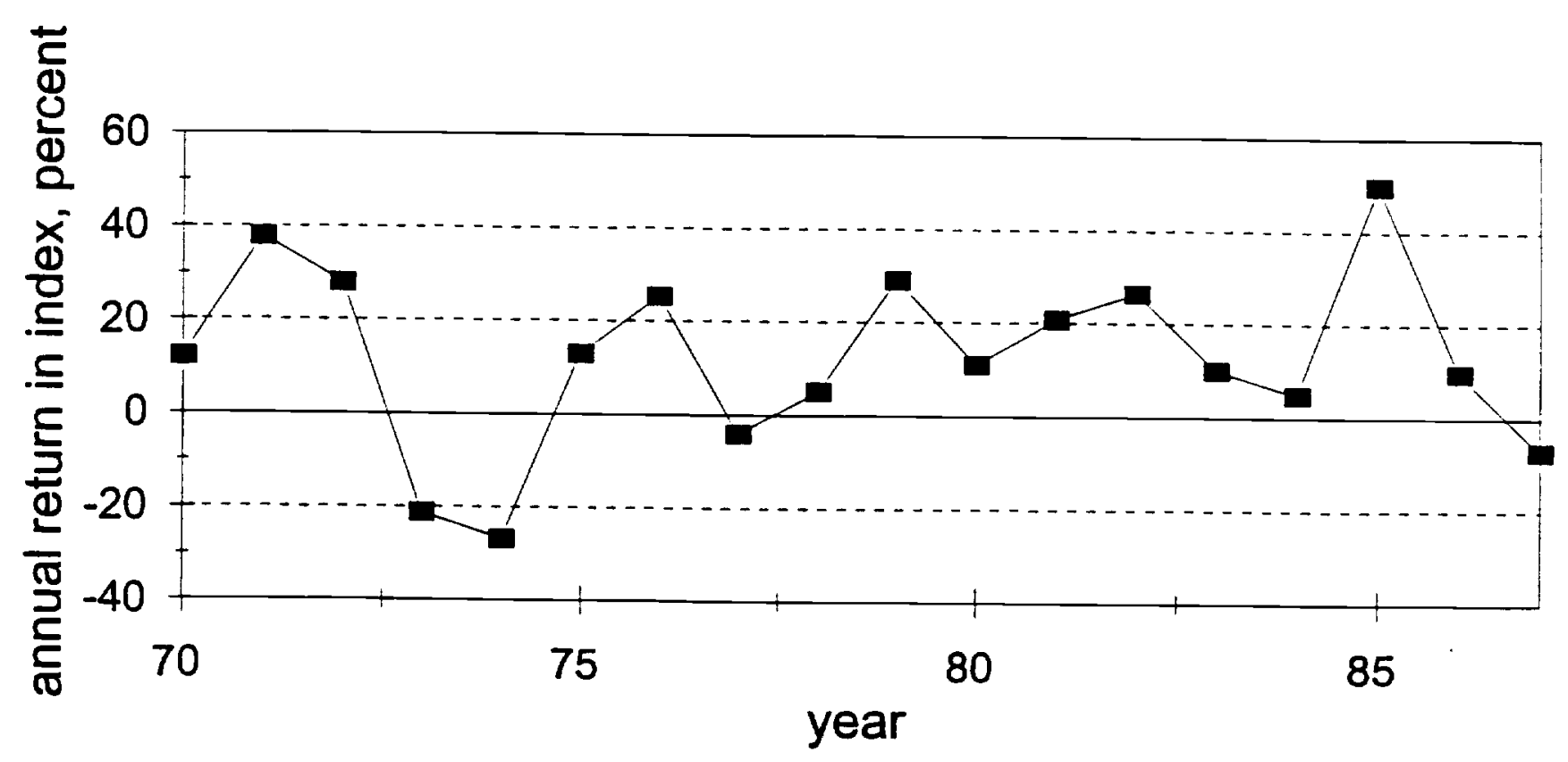




\section{Ratio of Income to Sales}

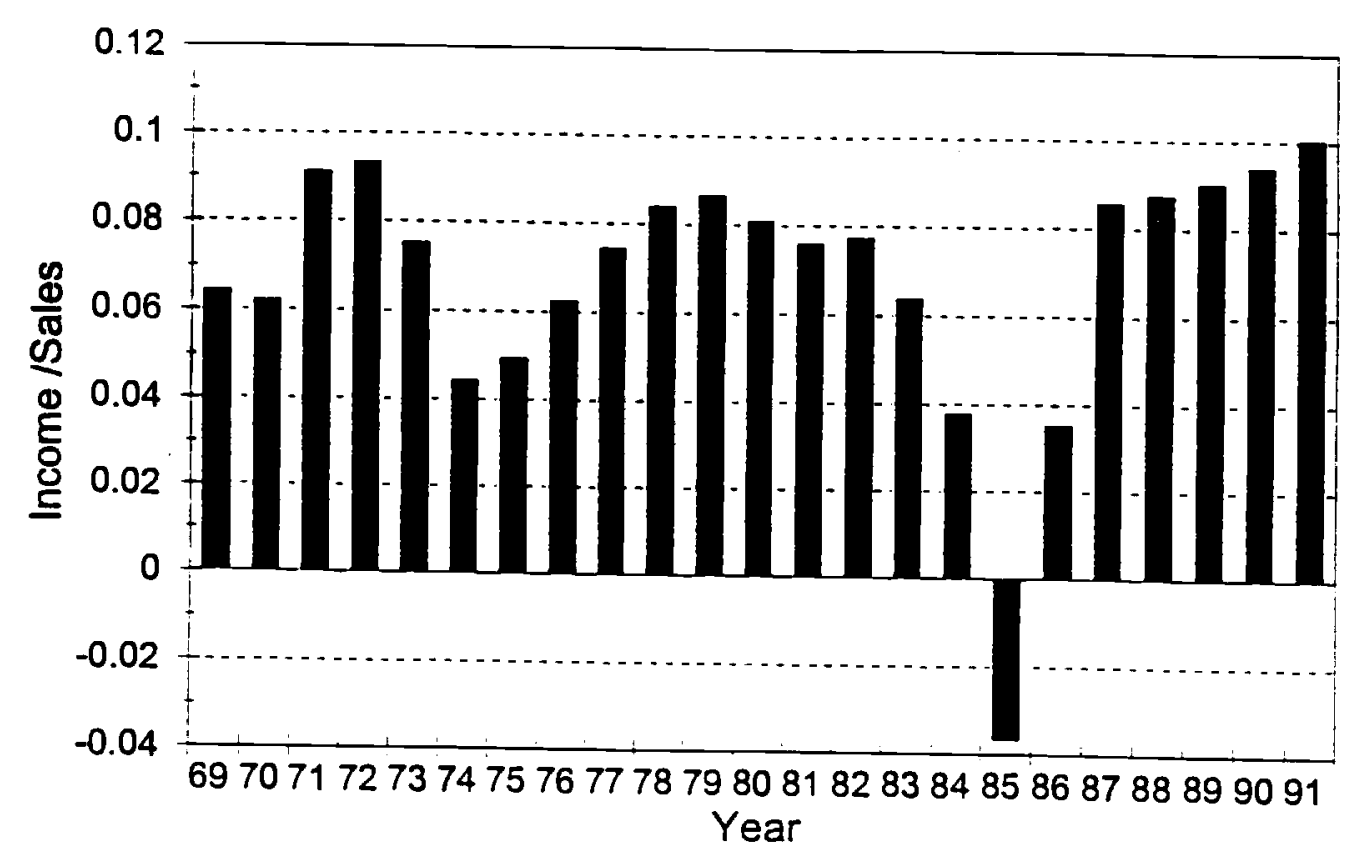

\section{Ratio of Income to Assets}

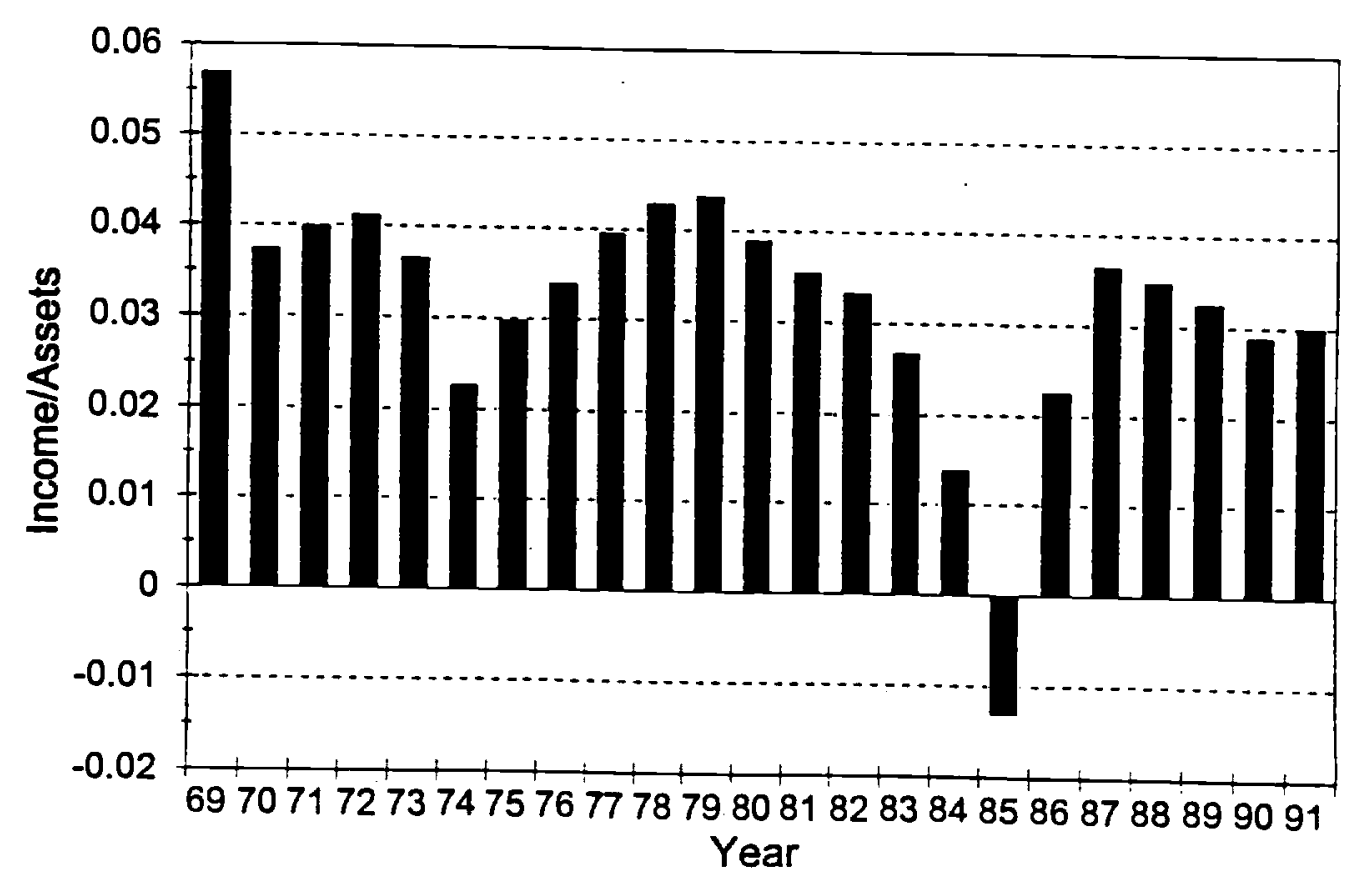


Figure II.5

Dividend Payout Ratio

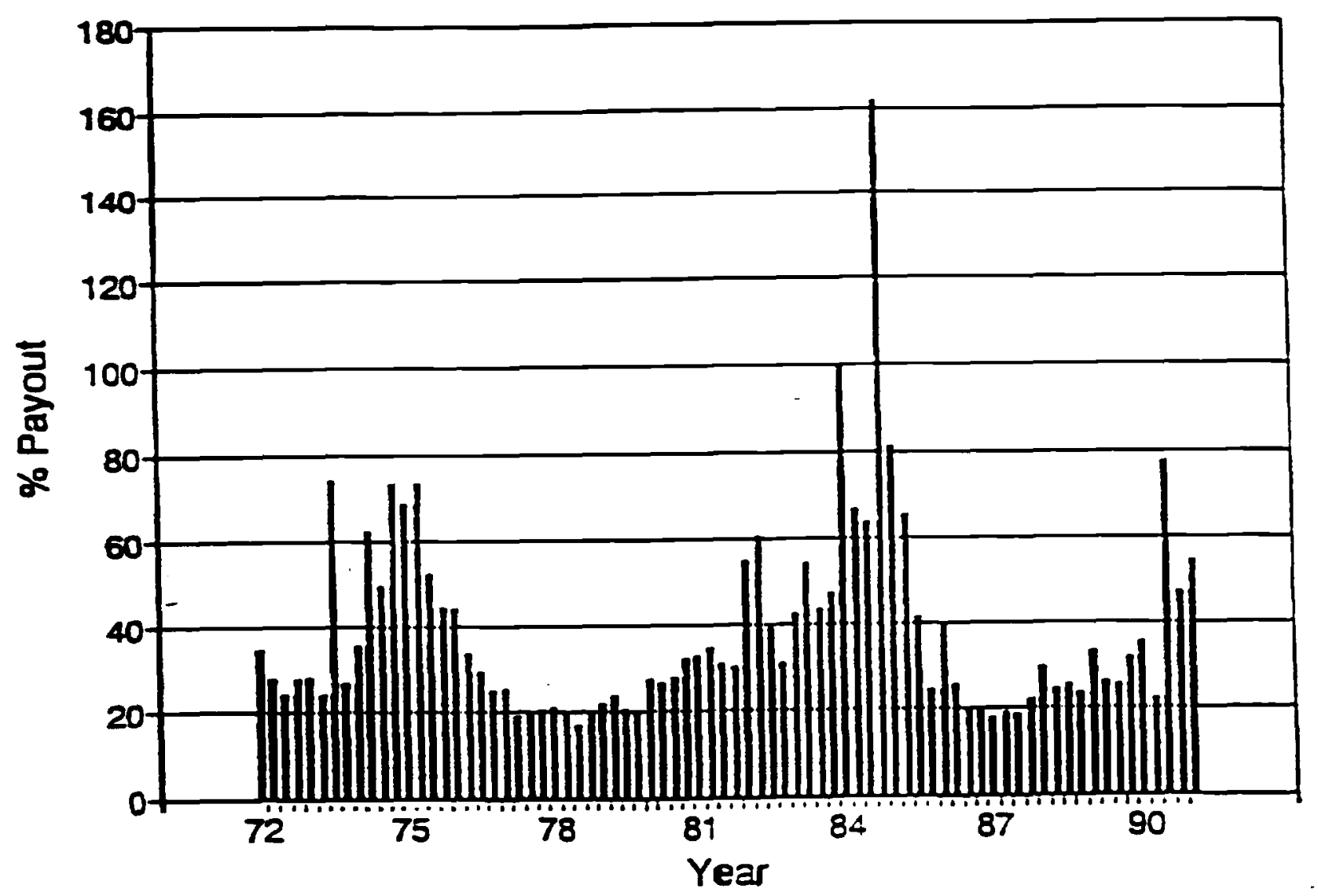


Figure II.6

\section{Growth in Stockholders' Dividends}

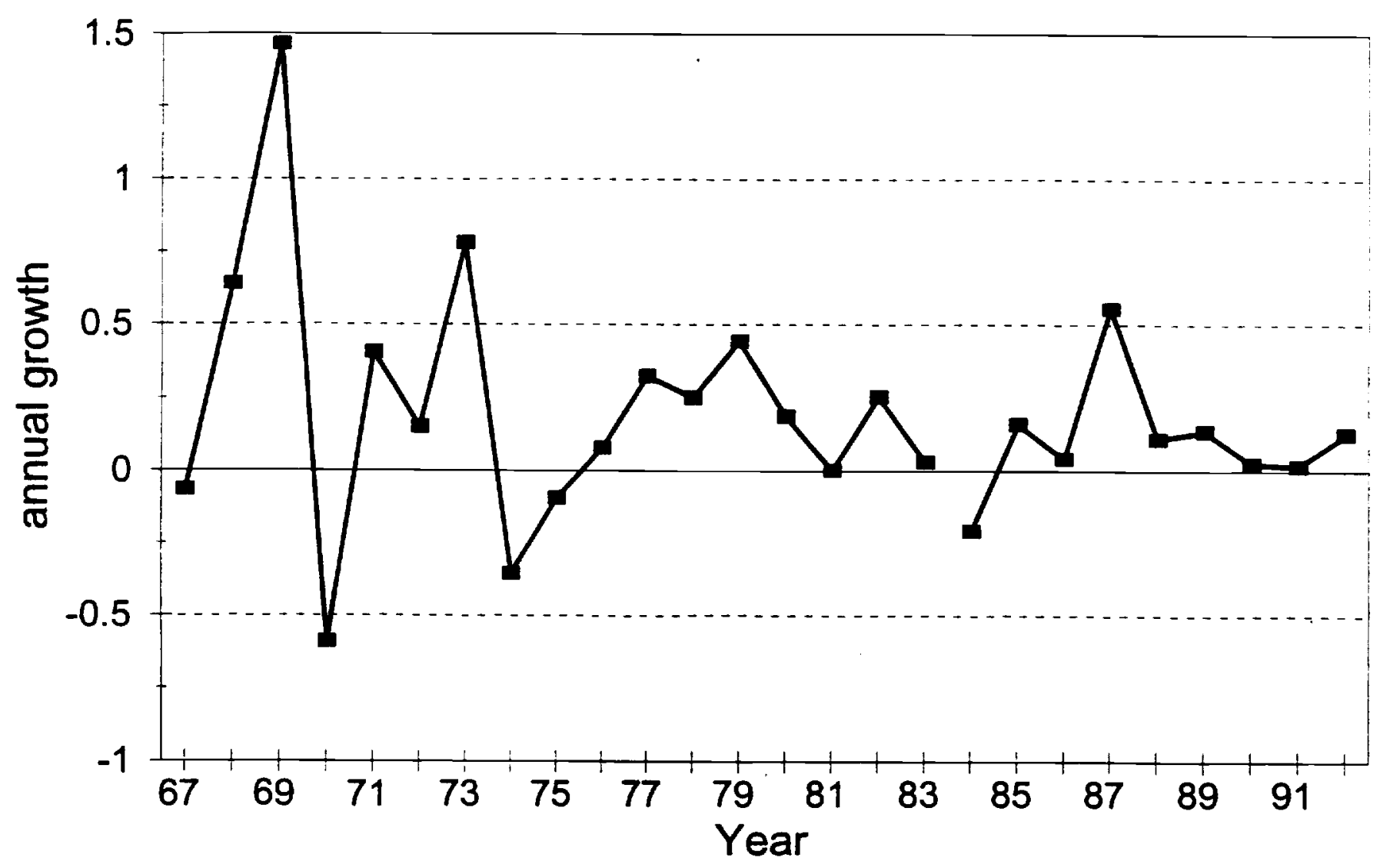


Figure II. 7

Repurchases

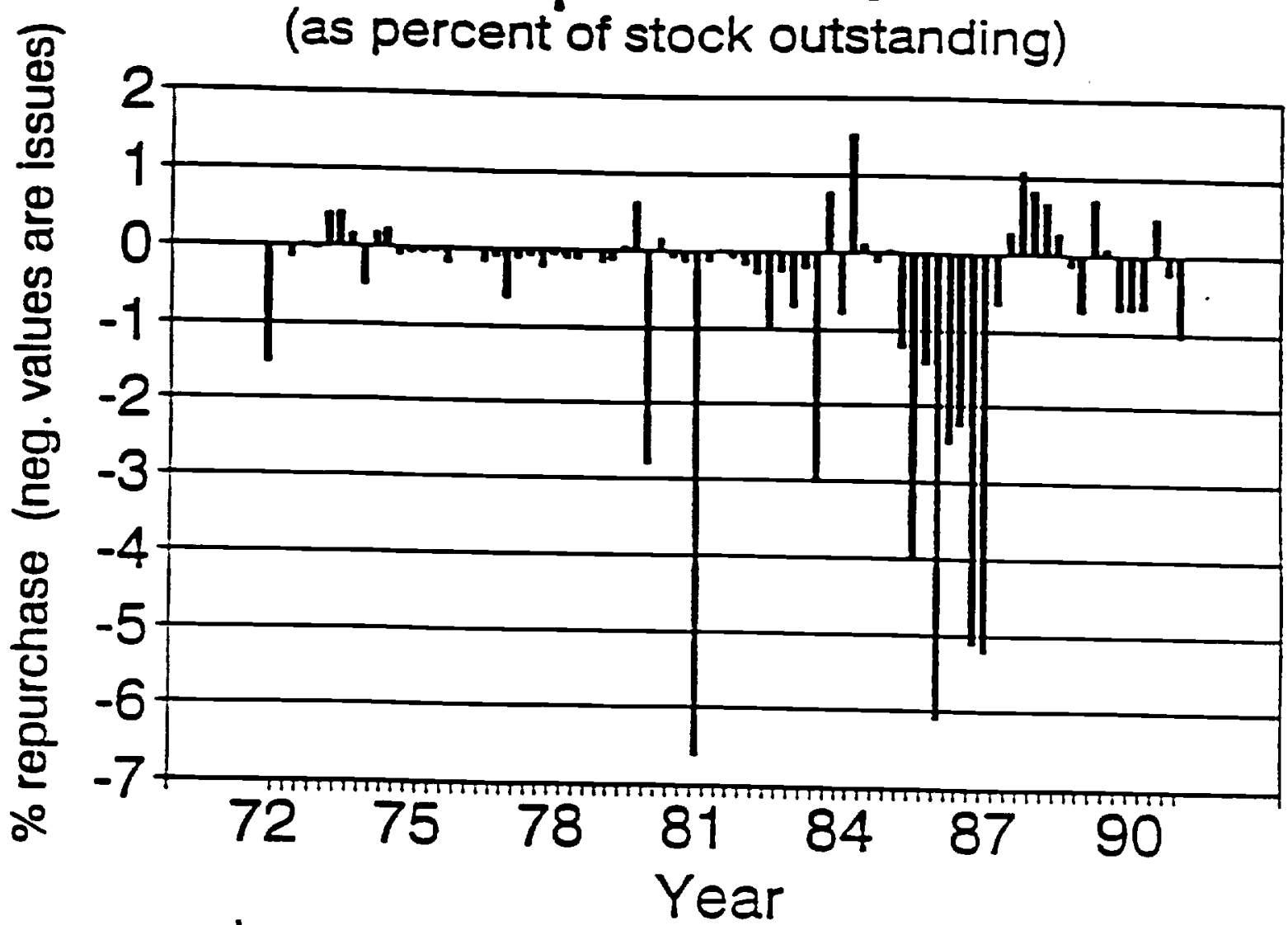


Figure III.1

\section{Equity relative to Net Worth}

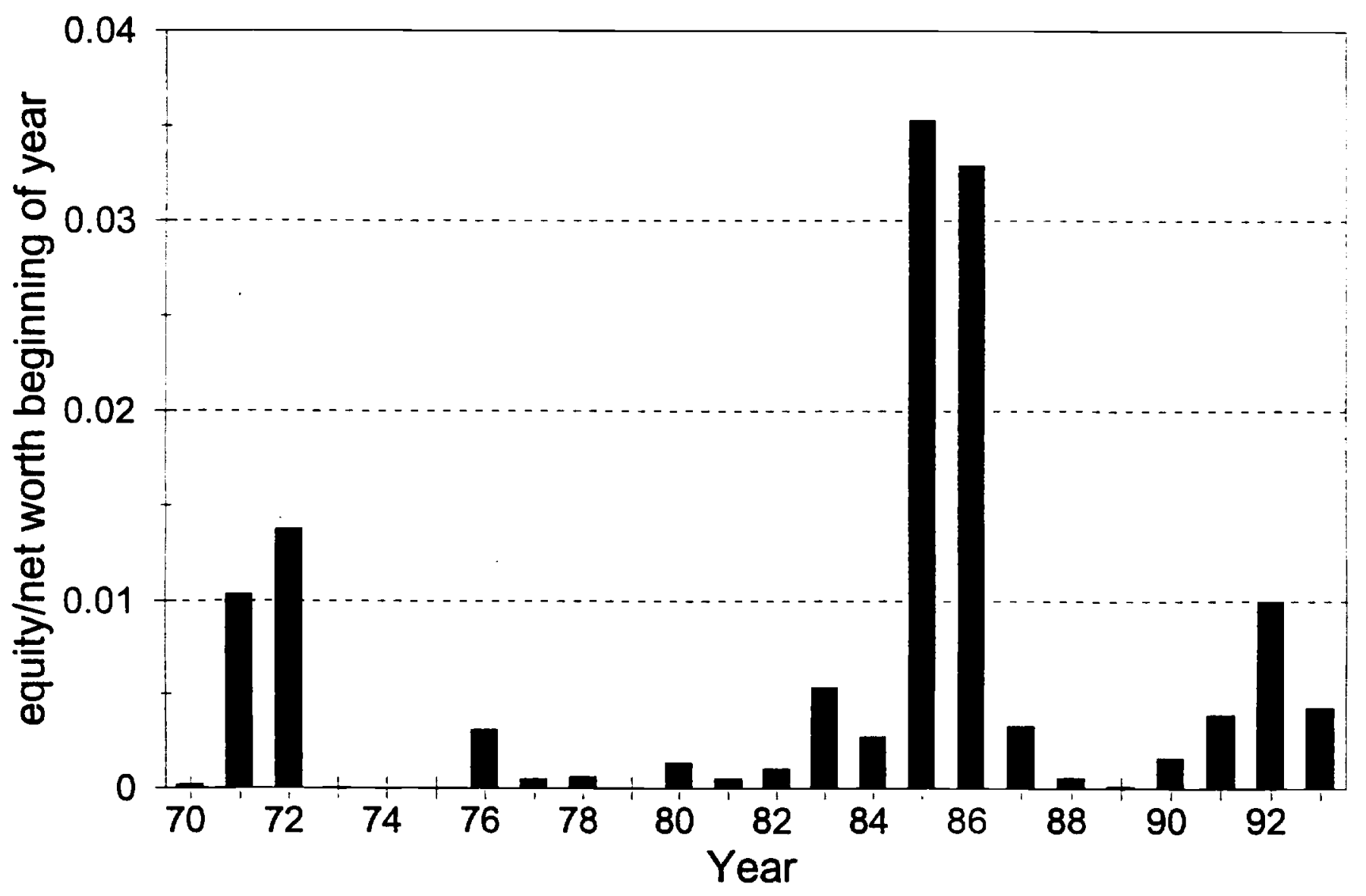


Figure III.2

\section{Debt Issues}

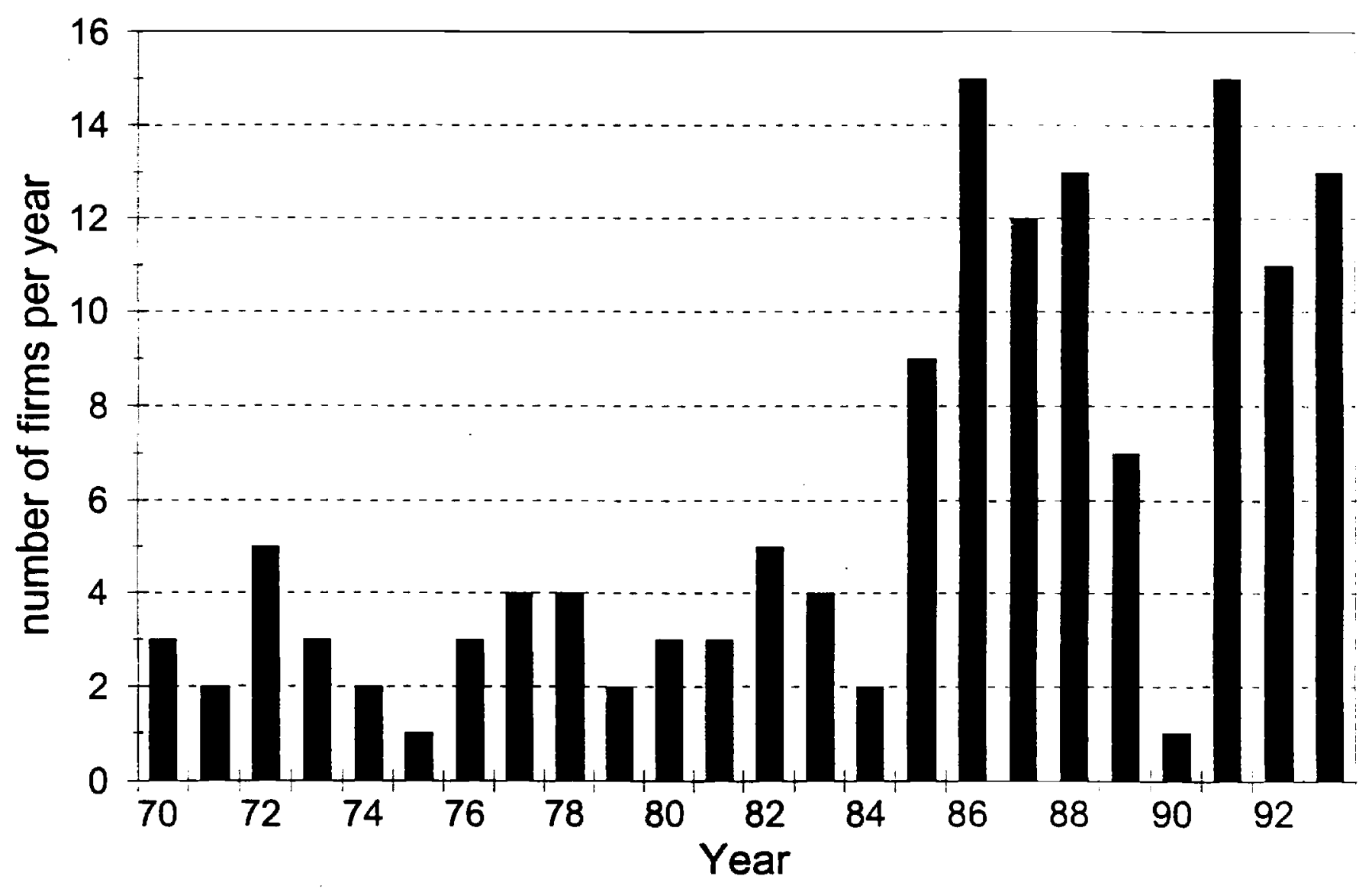


Figure III.3

\section{Debt Issue Relative to Net Worth}

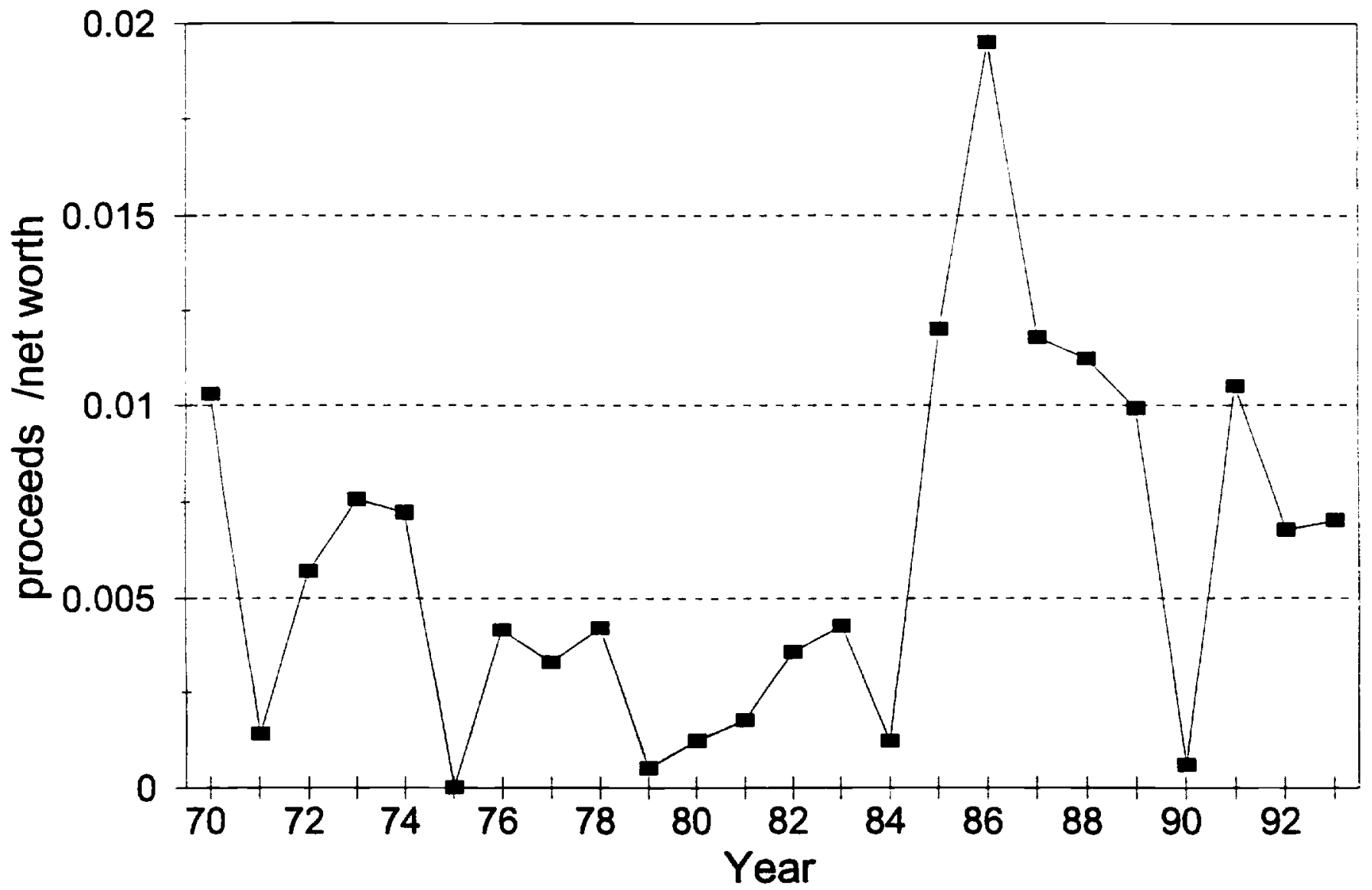


Figure III.4

\section{Debt by Maturity}

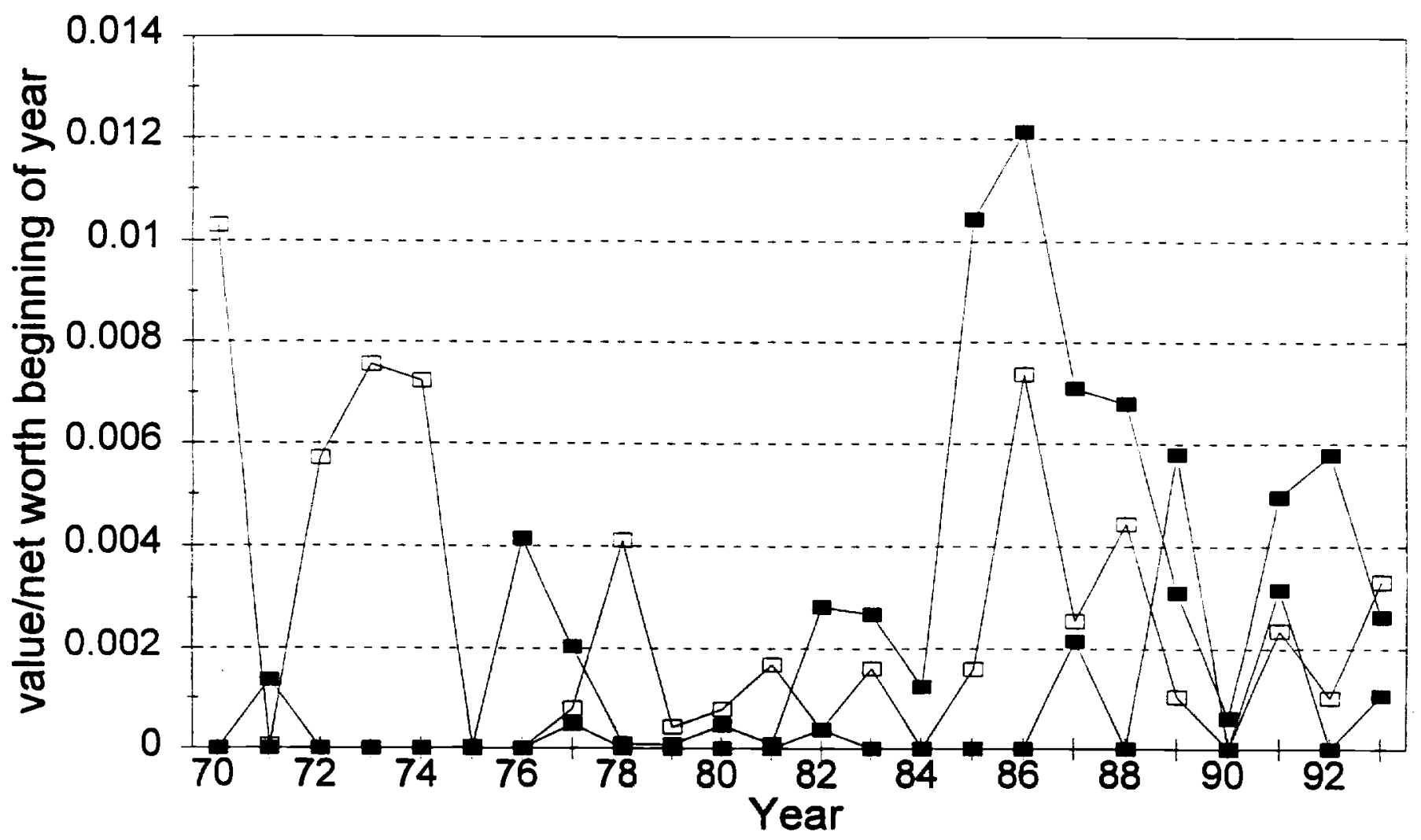

$\rightarrow$ short term $\rightarrow-$ medium term $=$ long term 
Figure III.5

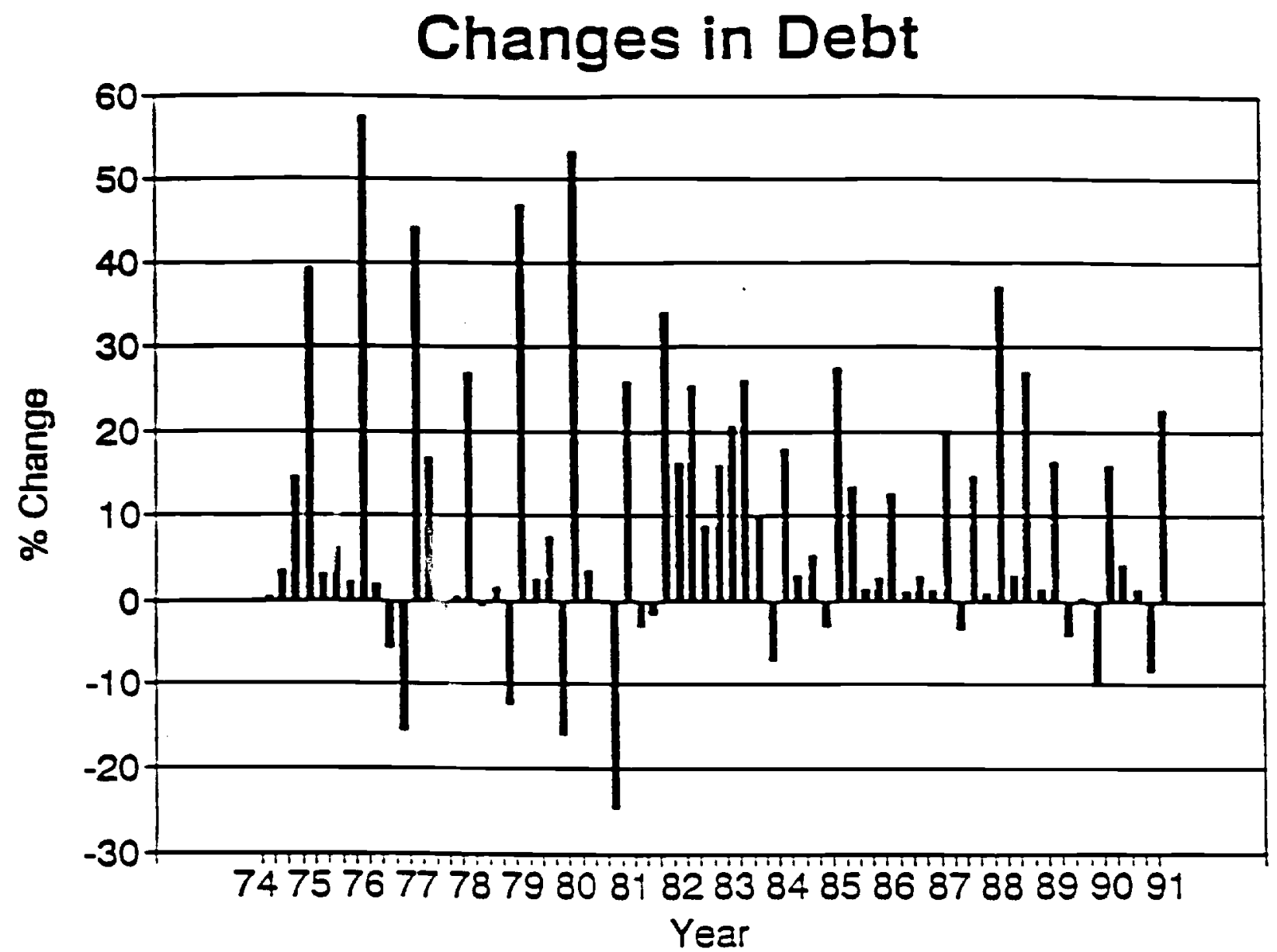


Figure III.6

\section{Long-term Debt \\ (as fraction of firm value)}

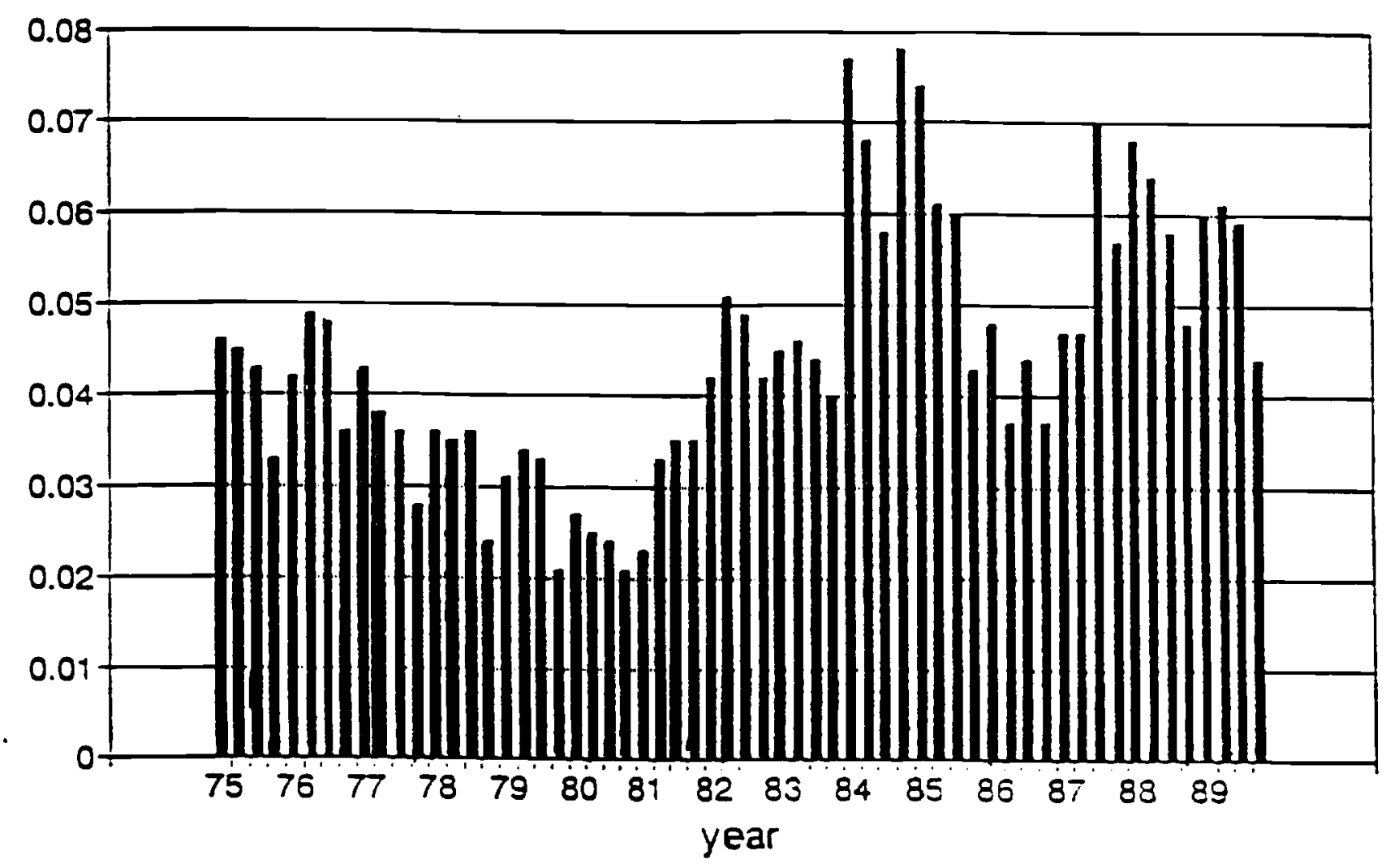


Figure III.7

\section{Growth in Industry Net Worth}

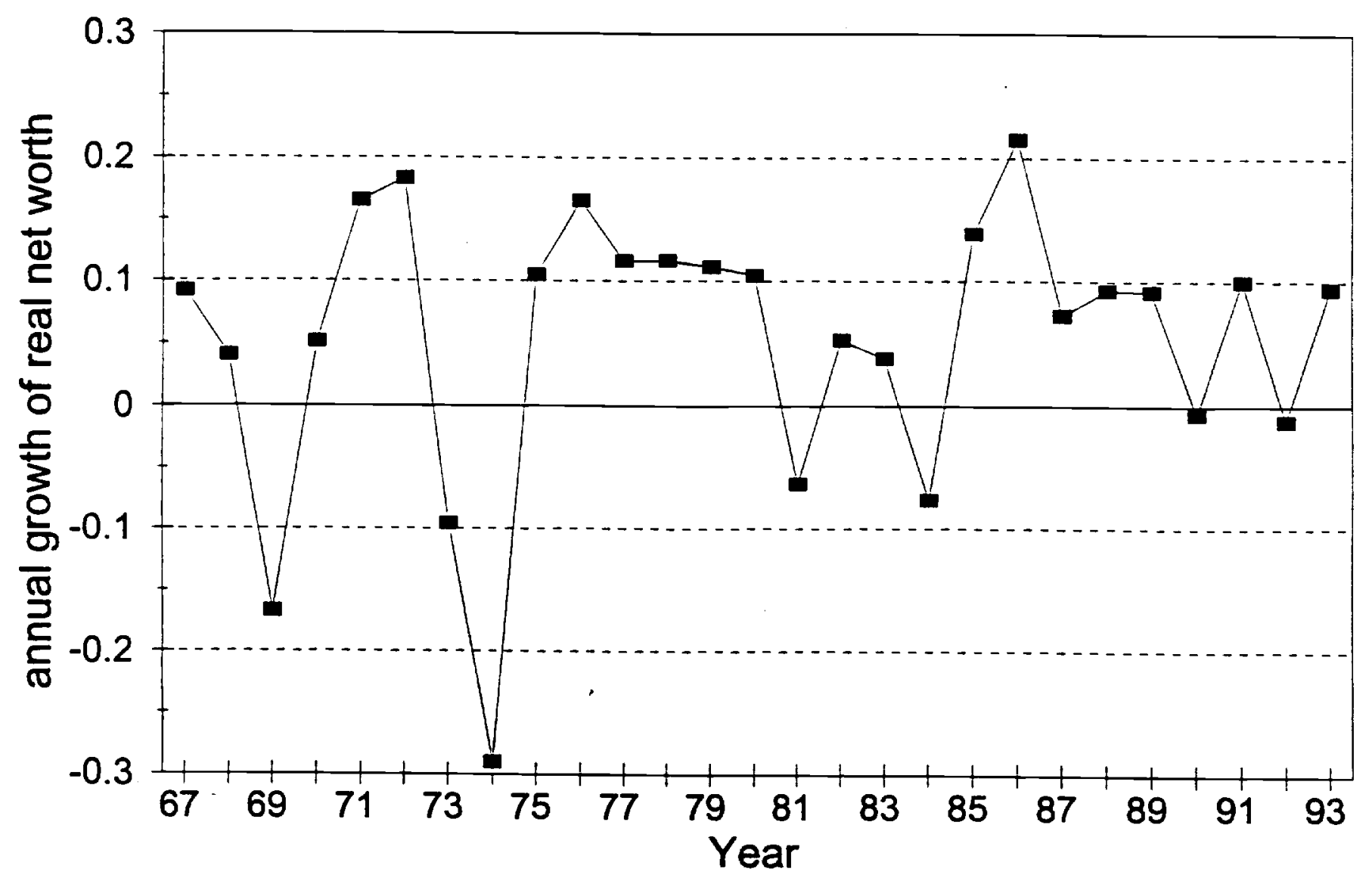


Figure IV.1

Equity Issues
Cumulative Abnormal Returns

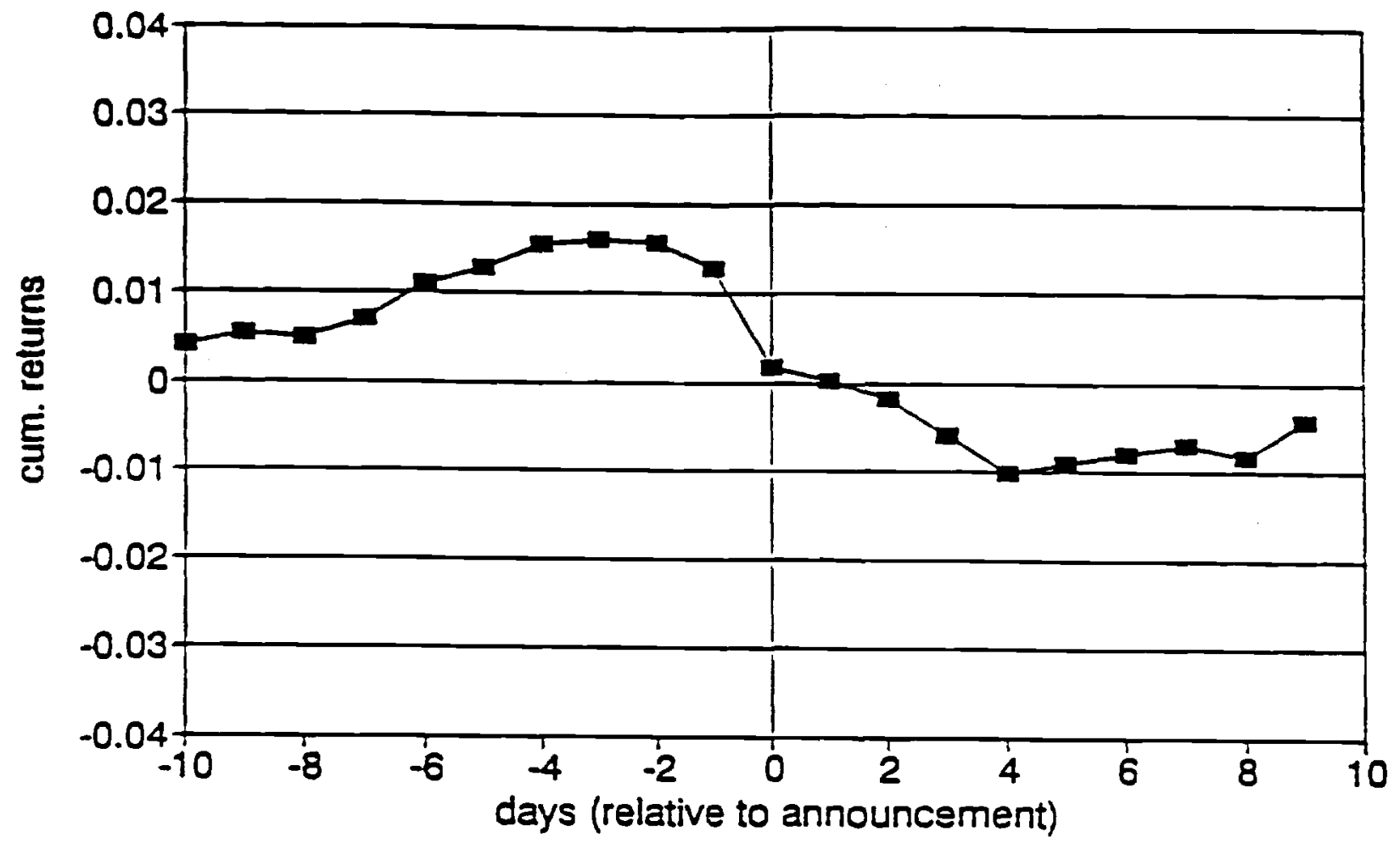




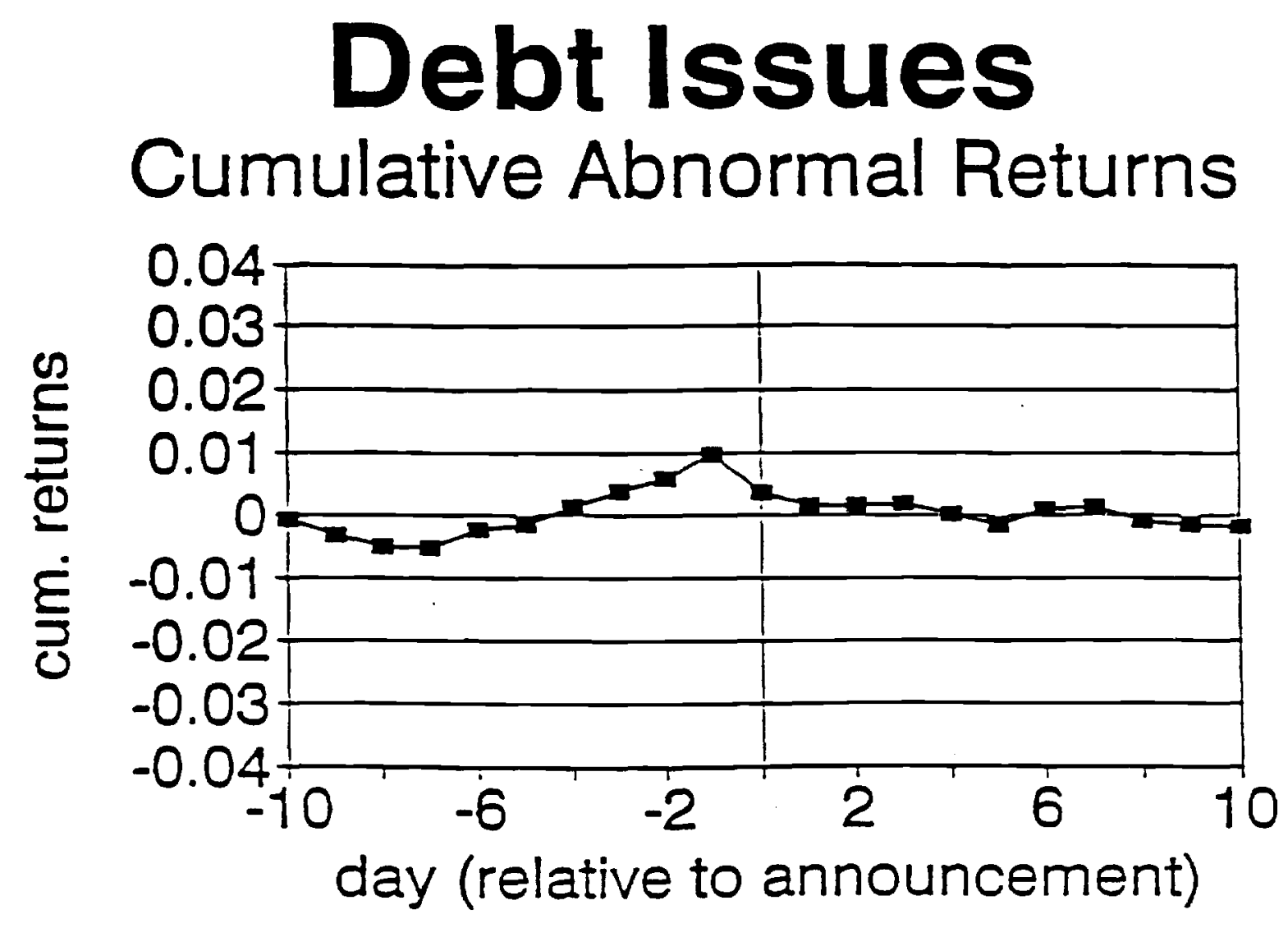


Table 1

Equity and Debt Issues

\begin{tabular}{|c|c|c|c|c|}
\hline year & $\begin{array}{c}\text { \# of equity } \\
\text { issues }\end{array}$ & $\begin{array}{l}\text { value of equity } \\
\text { issues (millions) }\end{array}$ & $\begin{array}{c}\text { \# of debt } \\
\text { issues }\end{array}$ & $\begin{array}{l}\text { value of debt } \\
\text { issues (millions) }\end{array}$ \\
\hline 1970 & 1 & 3.5 & 3 & 172.2 \\
\hline 1971 & 14 & 191.9 & 2 & 26.1 \\
\hline 1972 & 18 & 313.1 & 5 & 130 \\
\hline 1973 & 1 & 0.6 & 3 & 213.3 \\
\hline 1974 & 0 & 0 & 2 & 200.4 \\
\hline 1975 & 0 & 0 & 1 & 0.4 \\
\hline 1976 & 2 & 78.8 & 3 & 105 \\
\hline 1977 & 4 & 15.6 & 4 & 103.6 \\
\hline 1978 & 5 & 23.1 & 4 & 157.3 \\
\hline 1979 & 0 & 0 & 2 & 22.7 \\
\hline 1980 & 4 & 72 & 3 & 66.9 \\
\hline 1981 & 2 & 35.2 & 3 & 116 \\
\hline 1982 & 2 & 71.5 & 5 & 241.5 \\
\hline 1983 & 7 & 404.5 & 4 & 322.8 \\
\hline 1984 & 4 & 222.7 & 2 & 99.8 \\
\hline 1985 & 29 & 2787.9 & 9 & 947.5 \\
\hline 1986 & 29 & 3067.5 & 15 & 1816.6 \\
\hline 1987 & 6 & 386 & 12 & 1369.7 \\
\hline 1988 & 4 & 69.5 & 13 & 1443 \\
\hline 1989 & 1 & 15.5 & 7 & 1445.3 \\
\hline 1990 & 4 & 272 & 1 & 99.9 \\
\hline 1991 & 6 & 669.3 & 15 & 1813 \\
\hline 1992 & 14 & 1968.5 & 11 & 1338.2 \\
\hline 1993 & 14 & 860.9 & 13 & 1408.6 \\
\hline
\end{tabular}




\section{Table 2}

\section{External Financing and Industry Capacity}

depends :it \# equity real value of val. equity \# debt real value of val. debt variabl ::: issues equity issues issues /net issues debt issues issues / net

explan. variable :

capacity

liab/assets

$-13.54 \quad-1471.68$

worth

$-455.30$

$(-1.54) \quad(-1.69)$

49.58

7612.00

(2.06)

$\mathrm{R}^{2}$

(1.33)

.21
$-3.50$

$-.017$

$(-1.72)$

.06

(1.45)

.16
(-.82)

(3.20)

$(-.81)$

58.61

6530.88

(2.79)

.27 worth

$-.006$

.03

.11

Notes: $t$-statist $:$; in parentheses. All regressions have 24 observations. 
Endnotes

1. It has been suggested, however, that in the aftermath of a major disaster, the disruption in established policyholder relationships may result in a longer time to build.

2. See also the models of insurance pricing with possible capital shortages by Cummins and Danzon (1991), Harrington and Cagle (1994) and Doherty and Garven (1995).

3. One explanation for the price drop is that the riskiness of equity exacerbates problems of asymmetric information, since purchasers anticipate issues by predominantly over-valued firms (Myers and Majluf (1984)).

4. This research also contributes to the literature on the link between firm financing and real market outcomes, much of which explores the effect of decreased liquidity on real firm decisions. Recent theoretical and empirical work (e.g., Fazzari, Hubbard and Petersen (1988), Chevalier and Scharfstein (1994)) suggests that competition among firms is weaker, and price/non-capital cost margins are higher, when firms and the industry are more liquidity-constrained. A similar pattern is observed in the property-casualty industry: when industry capacity is low the price of insurance relative to non-capital costs is higher, perhaps reflecting a temporary increase in the opportunity cost of capital.

5. Unless otherwise noted, the data described here are from Best's Aggregates and Averages.

6. Price and quantity data would be preferable for describing market conditions, but they are not available. Other profitability series show the same time series pattern (Stewart (1985)). Due to accounting practices, income from insurance premiums tends to reflect pricing conditions for the previous as well as the current accounting period. Therefore the greatest increase in profitability will not necessarily coincide with the largest increase in prices. Anecdotal evidence confirms that pricing changes occur around the time accounting profitability changes. Gron (1994a) and Cummins and Outreville (1986) provide useful discussions of insurance accounting.

7. Net worth divided by a historical average is also used in Winter (1991) and in Gron (1994b). A different measure of capacity, industry net worth divided by GNP, displays a similar pattern, and is used in Gron (1994a and 1994b). For a more detailed exploration of the capacity-price time series relationship see Gron (1994b).

8. Stock index data are from van Aartrijk (1985) and Best's Review (February, 1985).

9. Two firms had negative equity for one year: Mission insurance in 1985 and Ambase in 1990. Mission was declared insolvent and liquidated in 1985. Ambase was reorganized in 1990. These observations were dropped from the sample. 
10. The OECD reports that internal funds comprise almost 80 percent of financing for U.S. firms in the period 1984-1988.

11. The data are from Best's Aggregates and Averages. The pre- 1983 series consists of aggregate stock company measures. The post-1983 series consists of consolidated data for all insurers. The large increase in 1969 is most likely a one-time adjustment due to the passage of the Holding Company Act.

12. The relatively large number of issues in 1992 and 1993 also appears to be consistent with high overall issue volume in this period.

13. This measure of short-term debt does not include bank loans which could be an important source of additional short-term capital.

14. Industry data are from Best's Aggregates and Averages as described in section II.

15. This argument presumes that undervalued firms have no way to credibly and inexpensively convey this information to the market. One also might argue that the price drop does not represent a cost to firms that are overvalued. Even for this group, however, firms acting in the interests of shareholders who would prefer to see their stock at a higher price will be reluctant to issue.

16. A parallel experiment for property-casualty insurers is complicated by the absence of a well-specified regulatory capital requirement.

17. The results are unchanged if an equally-weighted index is used to calculate abnormal returns. It is also possible to calculate $\beta$-adjusted abnormal returns, but this requires more financial data and generally makes little difference in this type of event study.

18. Because of the small number of issue events in each year, it is not possible to identify systematic changes in the price drop over time more finely.

19. It would be interesting to compare these statistics to the price response to issues in highprice constrained supply periods that do not correspond the hot market periods. Unfortunately only a few of the issues fall into this category so no meaningful comparison can be made. 